\title{
Eesti rahvussport - suurtest narratiividest variatiivse ja humoorika/iroonilise rahvaretoorikani
}

\author{
Piret Voolaid \\ Eesti Kirjandusmuuseumi folkloristika osakonna vanemteadur \\ Eesti-uuringute Tippkeskuse tegevjuhi ülesannetes \\ piret@folklore.ee
}

Teesid: Artiklis keskendun mõistete Eesti rahvussport, uus Eesti rahvussport, Eesti rahvuslik spordiala all tuntud alade tänapäevastele kasutustavadele nii internetimeedia kui ka rahvaküsitluse põhjal. Analüüs pakub nn rahvuslike spordialade liigendamisvõimaluse skaalal ametlik-mitteametlik, formaalnemitteformaalne.

Skaala ühes otsas on tõsimeelsed ametlikud, suuresti ajaloolistel, kultuuri- ja lokaalspetsiifilistel traditsioonidel põhinevad spordialad (nt raskejõustik, suusatamine jne), millel on Eestis olnud suur harrastajaskond ja publik ning milles on saavutatud rahvusvaheliselt kõrgeid kohti. Skaala vastaspoolde paigutuvad aasivad, retoorilised, keelelis-folkloorsed, kohati marginaalsed väljendused (nt tugitoolisport, alkoholitarbimine, meeleheide, poliitikute kirumine, koondamine), mille kaudu iseloomustatakse kohalikke rahvuslikuks peetavaid käitumismustreid ja stereotüüpe-hetketrende. Vajadus ükskõik mis spordiala nimetada või esitada etnilise aspekti kaudu on selgitatav rahvusliku identiteedi ja mentaliteedi loome mehhanismidega ning viitab spordi kultuuriliselt ja sotsiaalselt olulistele tähendusväljadele, samas võib sellisel kohati iroonilisel retoorikal olla rahvusvaheliselt universaalne ühisosa. Uurimuse eesmärk on vaatlusaluste mõistete kaudu neid tähendusvälju selgitada ja avada, tõstes esile rahva keeleloome variatiivsed aspektid ja huumoritaotluse. Sellisel juhul pole sportlikul vaatenurgal mingit tähtsust, oluline on rahvusspordi emotsionaalse klišee kaudu teatud inimlike (sh etnilisteks kvalifitseeruvate) stereotüüpide kuvamine, esiplaanile võivad tõusta nt rahvuslik eneseiroonia, selle klišee kaudu mahlakas sõnakasutus ajakirjanduses jne.

Märksõnad: etnilised stereotüübid, huumor, identiteet, iroonia, kujundlik keelekasutus, rahvussport, rahvuslikud spordialad, spordifolkloor 


\section{Sissejuhatuseks}

Ajal, mil maailm muutub üha globaalsemaks ja mitmekultuurilisemaks, on folkloristide-etnoloogide töödes ja teadusaruteludes iseseisva vaatepunktina aina rohkem esiplaanile tõusnud rahvusliku enesemääratlemise temaatika. Viimastel aastatel on Eestis rohket uurimisainest pakkunud näiteks rahvuskultuuri mõtestamine mitmesugustes kultuurinähtustes, sealhulgas kirjanduses ja kunstis (nt Undusk 2008), nimetamist väärivad toidu rahvuslikud tähendusväljad (nt Vahtramäe 2015; Laineste 2014), aga samuti rahvuslik rõhuasetus laulukultuuris, muuhulgas laulva revolutsiooni väljendustel (nt Schmidchens 2013; Särg 2015).

Üks läbi aegade võimsaid rahvustundeid esile kutsuv valdkondi on sport, mille mõjuvõim on väga laialdane. Muuhulgas näeme spordi mõju näiteks kujundlikus keelekasutuses. Rahvusspordi otsimiseks on Eesti avalikkuses kõlanud viimastel aastatel mitmeid üleskutseid (nt Hussar 2012; Rand 2007), sageli on seda vajadust kuulutanud spordiajakirjanikud. ${ }^{1}$ Seejuures on ajakirjanikud ja spordiraamatute autorid-koostajad ka ise mõne spordiala oma kirjaloominguga rahvuslikuks põlistanud, nt Tiit Lääne (2007) toeka teose pealkiri "Suusatamine - Eesti rahvussport" ei luba kahelda selle spordiala rahvuslikus oreoolis.

Üldjuhul rahvusspordi otsingute põhjuseid ei sõnastata, kuid enamasti paistab selle taga olevat väikese rahva püüd enesetõestuse ja -teostuse järele. Tõsimeelsed rahvusspordi ihalused langevad kokku rahvusluse idee modernistlike vaatenurkadega, milles sport nagu muudki valdkonnad (kirjandus, kunst jne) sobib ideaalselt modernismile omaste suurnarratiivide konstrueerimiseks (rahvuslikkusest ja postmodernistlikust mängust kirjanduses vt nt Viires 2008). Nii nagu rahvuskultuur on ühele rahvusele omane kultuur, mis tavaliselt on seotud ühe keele ja ajaloolise paiknemisalaga, on ka rahvussporti kombeks seostada konkreetse rahvuse ja rahvusriikliku esindatusega. Sport kui rahvusvaheline valdkond võimaldab saada kaugemal nähtavaks, sport "moraalse ja rahvusliku tugevuse loojana" (Vaiksaar 1999: 29) on olnud pidevalt ühiskondlikult oluline.

Käesoleva uurimuse eesmärk on analüüsida rahva arvamust Eesti ja eestlaste rahvusspordi kohta. Huvisfääris on esijoones rahvusspordi iroonilised ja/ või humoorikad kategooriad, mida ei saa aga uurida isolatsioonis reaalsetest ja tõsimeelsetest (rahvus)spordialadest. Enamgi veel - tihti jäävad tõsiste ja koomilisele orienteeritud nalja-spordialade piirid hägusaks. 2017. aastal selle uurimuse tarvis korraldatud küsitlus näitas, et küsimuses, mis on Eesti ja eestlaste rahvussport, on igaühel oma ettekujutus, 250 vastajast jäi kõigest mõni üksik vastuse võlgu. Vastustes sisalduvate selgituste põhjal analüüsin, millised markerid saavad oluliseks mingi spordiala rahvusspordina määratlemisel, olgu tegu tõsimeelse või iroonilise ja/või naljaka spordialaga. Uurimuses on kesksel kohal kolme tasandit kirjeldavad, kohati kattuvad mõisted. Esiteks rahvus- 
sport ehk rahvuslik spordiala on väga lihtsustatuna nii Eesti territooriumil kui ka eestlaste tehtud tõsiselt võetav saavutussport (reaalne võistlussport)2; kuid käesolevas uurimuses saab iroonia antidiskursuses retooriliseks klišeeks ja kaugeneb igasugusest tõsiseltvõetavast sporditegevusest ja sellisel juhul kasutan ka mõistet naljaala või naljasport. Teiseks rahvalik sport, mis katab esijoones meelelahutuslikud, seltskondlikud ja rahvalikud spordimängud, mis kuuluvad nt rahvuslike traditsiooniliste kalendritähtpäevade (nt jaanipäeva) ja muude koosviibimiste (nt sünnipäevade) kombestikku. (Eestis sobituvad sellesse liigitusse klassikaliselt köievedu, sangpommi rebimine, vägikaikavedu jne.) Kolmandaks rahvasport, mis kattub tihtipeale tervisespordi, liikumisharrastuse ja harrastusspordi mõistega (Siimann 2014) ning selle keskne motiiv on kehaline aktiivsus tervise säilitamiseks ja tugevdamiseks ning kehaliste võimete arendamiseks. Analüüsiosas lähtun neist uurijatest (nt Brubaker 2009), kes on rõhutanud rahvuslikkuse muutuvust ja teatud olukordades aktualiseeruvat loomust.

\section{Pärisspordialad rahvusspordi staatuses Eestis läbi aegade}

Ajaloolased (Tamm 2003: 66) on osutanud rahvusliku ajaloomälu lahingukesksusele. Nii nagu on võidukad võitlused olnud algusest peale rahvusliku identiteedi ja monumentaalse mineviku lahutamatu osa, nii on ka võidukad spordilahingud olnud olulised rahvusliku identiteedi ehituskivid.

Edumaa reaalsete ametlike spordialade rahvusspordialana käsitlemisel on olnud neil spordialadel, milles on saavutatud häid tulemusi väljaspool Eestit. Tiitlid ja kõrged kohad (eeskätt olümpiamängudelt ja maailmameistrivõistlustelt) on ajalooliselt muutuv marker, mistõttu on saavutuste põhjal Eestis eri aegadel olnud populaarsed eri alad.

Spordi tõsiseltvõetavusele aitab kindlasti kaasa institutsionaliseeritus, 2017. aastal on Eesti Olümpiakomitee liikme staatuses 76 spordialaliitu, lisaks on olemas veel 23 eraldiseisvat alaliitu (http:/www.sport.ee/et/aruanne/ spordialaliidud). Arvud on kõnekad ja näitavad Eestis harrastatavate spordialade rohkust, samas seostatakse rahvusliku spordiala rolliga neist väheseid. Nii saame 19. sajandi lõpus ja 20. sajandi alguses rääkida raskejõustiku - maadluse ja tõstmise - võidukäigust. Maailma paremikku kuulusid elukutselised maadlejad Georg Lurich, Georg Hackenschmidt ja Aleksander Aberg, kellest kujunesid rahvuslikud müüdid. Nende eeskujul hakati maadlust laialdaselt harrastama, tekkis palju raskejõustikuklubisid ja alaga tegelemine viis Eesti raskejõustiklaste pideva eduni olümpiamängudel. ${ }^{3}$ Rahvusspordi teise markerina saabki nimetada ühe spordiala suure harrastajaskonna ja eestkõnelejate olemasolu. Sellisel juhul iseloomustavad spordiala lisaks 
eespoolnimetatud rahvaspordi motiivid. Kuigi rahvasporti saab saavutusspordist eristada, võib ka siin spordile omane võistlusmoment alles jääda.

Eesti rahvussporti käsitledes ei saa alati rääkida iseseisva riigina oma lipu all tehtud spordist. Eelmainitud raskejõustiklaste näide kinnitab, et juba Tsaari-Venemaa võimu all oli eestlastele tähtis edukas olla ja silma paista impeeriumi teiste osade seas. Eesti okupeerimise järel 1940. aastal peatas Nõukogude võim kohalike spordiorganisatsioonide tegevuse, samas hakati pärast Teist maailmasõda kujundama Eesti sporditegevust Nõukogude Liidu süsteemi kohaselt. Eestis asutatud spordiühingute meeskonnad võistlesid Nõukogude Liidu võistlustel ning NSV Liidu võistkondade koosseisus esinesid Eestist pärit sportlased ka rahvusvahelistel võistlustel. NSV Liidus saavutasid kõrgeid kohti Eesti korvpallurid, kergejõustiklased, ujujad, purjetajad, raskejõustiklased, rattasportlased, auto-motosportlased, maletajad jpt. Eesti sporditaristule andsid tõuke 1980. aastal Moskvas toimunud olümpiamängud, mille purjeregatt toimus Tallinnas (rajati nt Pirita purjespordikeskus). Nii oli sport nõukogude ajal eestlastele rahvuslike tunnete väljaelamise üks vahendeid ja Eesti sportlaste edu oli tihtipeale ka kohalik rahvuslik edu.

1988. aastal võistlesid Eesti sportlased Souli olümpiamängudel veel Nõukogude Liidu võistkonnas, sellegipoolest tervitati Eestis nt Erika Salumäe kullavõitu naiste jalgrattasprindis juba kui rahvuslikku triumfi. Nõukogude Liidu korvpallimeeskonna liikmena pälvis kuldmedali ka Tiit Sokk. Salumäe ja Soku vastuvõtt Tallinna Raekoja platsil oli laulva revolutsiooni üks tipphetki, kus lehvitati loosungit "Eesti ise Barcelonasse" (vt nt Paal 2017: 17).

Üldistavalt on 20. sajandi lõpust tänapäevani rahvuslikku identiteeti ja mentaliteeti mõjutavad alad olnud pigem murdmaasuusatamine, kergejõustik, pallimängud (vt nt Lään 2002; Vaher 2010).

Rahvusspordi kolmanda markerina võib välja tuua lokaalsed eripärad, mis mingi spordiala levikule kaasa aitavad. Nt suusatamise kujunemisel rahvusspordiks on vaieldamatult tingimuseks kohalikud kliimaolud ja lumised talved. Kohaliku eripära järgi võib mingi spordiala ka Eestis sündinud (leiutatud ja kasutusele võetud) olla. Just selle parameetri järgi annab rahvusliku spordiala mõõtme välja 1990. aastatel leiutatud kiiking.

Rahvuslikuks võivad tõusta ka uued haruldased, ühtlasi kummalised spordialad, milles peetakse rahvusvahelisi tiitlivõistlusi, mis on ilma alaliidu institutsioonita, ent siiski rahva hulgas teatud ja väga tugeva meelelahutusliku komponendiga. Nii on viimastel aegadel eraldi kohaliku spordialana üldsuse tähelepanu võitnud sääsepüüdmine, milles 2010. aasta juunis toimusid esimesed, 2017. aasta suvel kolmandad Eesti meistrivõistlused (Ingver 2017). Idee on pärit Soomest, kus korraldatakse sääsepüüdmise maailmameistrivõistlusi juba aastaid. Võistlusalana on Soome rahvuslikust spordimängust maailmameistrivõistluste tasemel spordialana Eestisse jõudnud ka nt saapaheide (2017. aasta 


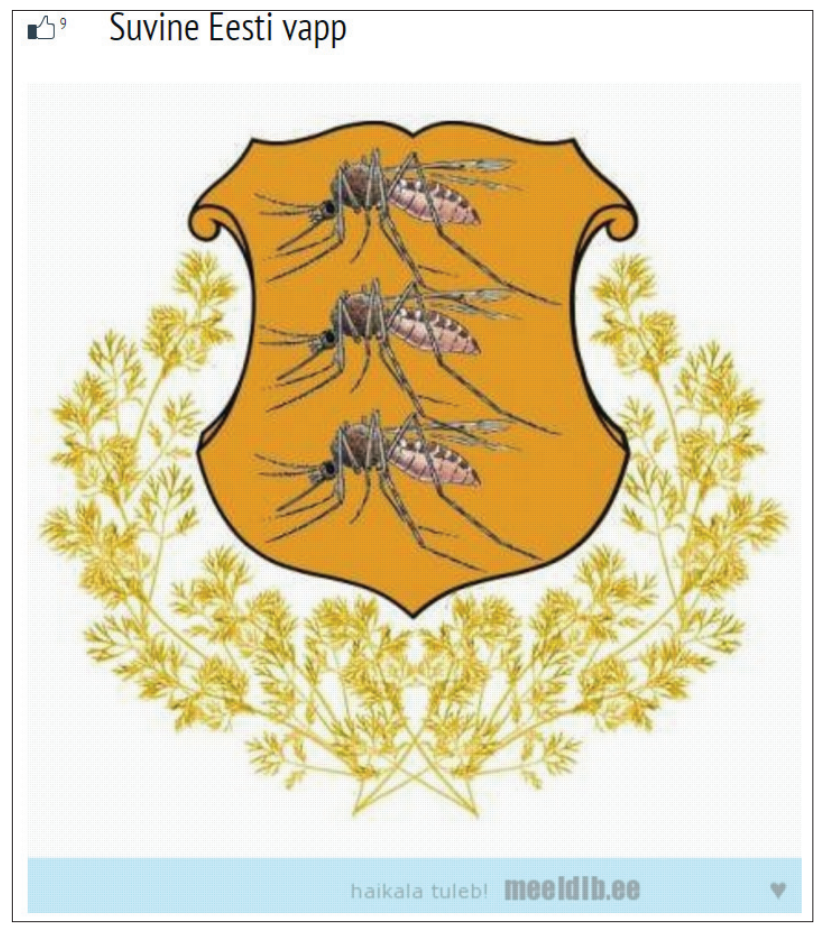

Joonis 1. Sääsepü̈̈dmine iseseisva spordialana on kantud seltskondliku meelelahutuse ja huumori taotlusest ning haakub sellekohaste temaatiliste meemidega. Asjaolu, et mõnel suvel kohtab Eestis erakordselt rohkelt sääski, on andnud ainest ka "Eesti suviseks vapiks”. (http: / / meeldib.postimees.ee/2012/02/suvine-eesti-vapp/\#_)

suvel toimus MM Viljandis). Niisiis ei pruugi rahvussport olla midagi unikaalset ja ühele rahvusrühmale omast, vaid laenatud naabritelt või kaugemaltki, see on mujalt imporditav. ${ }^{4}$

\section{Eesti rahvussport iroonia ja retoorika mänguväljal}

Siinse uurimuse tähelepanu all on ka väljend "Eesti rahvussport on ..." verbaalse huumori üldteooria (Attardo \& Raskin 1991) valguses klišee või skriptina, millesse saab nalja eesmärgil sobitada spordi tavapärasest tähendusest täiesti erinevaid tasandeid (nt rahvusspordiks võivad olla kriminaalsed alad, nagu surnuks joomine, eestlaste juveeliröövid välismaal). Loogiliste mehhanismide rikkumisega põhjustatakse häire ja vääranaloogia, mis tundub sobivas situatsioonis naljakas. Huumoriteoreetiliselt saame rääkida verbaalsest irooniast ja vastavalt esituskontekstile isegi iroonia agressiivsemast vormist - sarkasmist (iroonia ja sarkasmi piirid on enamasti väga hägused, vt Giora \& Attardo 
2014: 398). Pilkeobjektiks on etniline kogukond, kuhu naljarääkija ise kuulub. Keelelisel tasandil saab üldistavast klišeest "Eesti rahvussport on ..." strateegia või tööriist, mis võimaldab loomingulisi ja mängulisi kujundiülekandeid kõikvõimalike valdkondade vahel. Näiteks poliitikas realiseerub mõistemetafoor POLIITIKA ON SPORT. Poliitikast räägitakse sporditerminites väga sageli, nt spordivallast on laenatud väljendid meeskonnamäng, varumängija, pall on nüüd vastase poolel, pall on [kellegi] väravas, pink on pikk, punast kaarti näitama, võrdsetelt stardipositsioonidelt alustama, omaväravat lööma jne (vt ka Voolaid 2003: 212). Muude elualade nimetamine piltlikult rahvusspordiks on lihtne võte, kuivõrd konkureerimine on ükskõik mis eluvallas tänapäeval enesestmõistetav. Sünnist peale tuleb otse või kaude võistelda, olgu lasteaia-koha, eliitkooli pääsu või hea töökoha pärast, ühiskondlik toimimine on paljuski orienteeritud saavutustele ja tulemuste hindamisele nii nagu võistlusspordis. Kui spordis on saavutused enamasti arvuliselt mõõdetavad, siis kultuurilisel tasandil koostatakse tihtipeale pingeridu, mille kriteeriumid on algusest peale ebaselged ja raskesti mõõdetavad (kirjanike, muusikute, näitlejate, tuntumate naiste ja meeste jne pingeread). Projektipõhises süsteemis on "rahvussport" mingi nähtuse populaarsuse mõõdikuna tunnetuslikult lihtsasti mõistetav ja kujundlik ülekanne toimub väga kergelt: realiseerub mõistemetafoor ELU ON võIsTLus (nt kõigil on võrdne stardipositsioon; koolide, sissesaanute jne pingeread, eluetappide vahefinišid, elumaraton $)^{5}$.

Epp Annus on toonud välja, kuidas rahvuslus võib kirjandusteoses omandada postmodernse paatose ja sellest saab eneserefleksiivne, tõsiduseta, modernsest maailmapildist eemaldunud mänguväli (Annus 2006 < Viires 2008: 210; vt ka Annus 2000). Samasugune refleksiivsuse esiletõus on täheldatav rahvusspordi retoorilises empiirikas, kus rahvussport rakendatakse mänguliselt kogukondliku eneseiroonia vankri ette.

Mitmete uurijate (nt Hutcheon 1994) väitel kasutatakse irooniat mängulise antidiskursusena, et varjatud pilke kaudu öelda välja oma tõsine seisukoht valitseva idee suhtes. Iroonia on niisiis non bona fide mäng oluliste ideedega, sõnum on maskeeritud tõsidusega, jättes mulje tõsisest suhtlemisviisist (vt ka Voolaid 2014: 60). Kujundlikus diskursuses kasutatakse irooniat koomikavõttena, nimetades rahvusspordiks ootamatuid ja üllatavaid valdkondi, mida tõsises mõttes ei saa kuidagi spordina käsitleda. Nii pööratakse ka rahvusspordi suure narratiivi idee pea peale. Mängimine žanrite ja ideedega on iroonilise diskursuse põhialus. Huumori sotsiaalse identiteedi teooria järgi on huumor jagatud identiteet, mis on üks sotsiaalse rühma defineerimise aluseid (Tajfel \& Turner 1979). Nii rahvusspordi tõsine idee kui ka "suure ja tõsise asja" üle naljategemine väljendavad kogukonnasisest identiteeti. Etnilist enesekohast huumorit on käsitletud paljudes uurimustes, ja laialdaselt on osutatud selle võtte universaalsusele. Nii nagu rahvusvaheliselt tuntakse reaalseid spordi- 
alasid, nii on ka naljadiskursus rahvusvaheliselt levinud. Käesoleva artikli allikaines on eestikeelne, kuid edaspidi tuleb seda kindlasti võrrelda naaber-, aga ka teiste kaugemate rahvaste analoogilise materjaliga.

\section{Empiiriline aines ja analüüs}

Käesoleva uurimuse allikaines on kogutud erinevaid meetodeid ja uurimiskeskkondi kaasates. Põhiainese moodustavad 2017. aasta kevadel korraldatud nimetamisküsitluse 250 vastust nii sotsiaalmeedias kui ka käsikirjalistel küsitluslehtedel. Mõlemal juhul tuli vastata küsimusele: "Palun vastake, mis on Eesti ja eestlaste rahvussport. Oodatud on nii tõsised kui ka vähem tõsised variandid." Peale spordiala nimetamise selgitati pikemalt oma valikuid või seisukohti kõnealuses küsimuses.

Internetis oli võimalus vastata märtsis 2017 Eesti Spordi- ja Olümpiamuuseumi Facebooki lehe (http://www.facebook.com/spordimuuseum) postituse kaudu. Lehel oli küsitluse ajal 1400 jälgijat eri vanusest ja eri elualadelt, postitust jagati üle 50 korra ja postituse kommentaaridesse vastas ligi 80 inimest, kes esinesid Facebooki keskkonnas oma nime all.

170 käsikirjalist vastust laekus kahe Tartu kooli - Tartu Tamme Gümnaasiumi (TTG) ja Tartu Hugo Treffneri Gümnaasiumi (THTG) - noortelt, kes olid vanuses 16-18 aastat ja vastasid anonüümselt.

Internetimeediast pärineb lihtviisilise internetiotsingu teel kogutud juhuslikum osa ainesest. Selle põhjal vaatlen, mida on Eesti rahvusspordina nimetatud ja millistes kontekstides käsitletud erinevates artiklites, kirjutistes, kommentaarides ja postitustes.

\section{Pärissport rahvusspordina}

Reaalsete spordialade rahvusspordina määratlemisel on vastajad välja toonud põlvkondlikku järjepidevust, traditsioone.

Rahvussport on midagi, millega just üks kindel rahvas tegeleb ning millega on tegelenud mitu põlvkonda (THTG, 6.6.2017).

Vastustes toodud selgitustest ilmneb rahvusspordi eespool kirjeldatud muutuv ja temporaalne iseloom:

Ilmselt saab igaüks sellest sõnast omamoodi aru. Kui lähtuda sellest, et rahvussport võiks tähendada spordiala, mis on paljude eestlaste hulgas (mingil ajal) väga populaarne. Tundub, et sõltub kõige rohkem sellest, mis alal eestlastel parasjagu hästi läheb. Sel nädalal ehk tennis. (THTG, 
25.5.2017 - vihje eesti tennisisti Anett Kontaveiti edukale esinemisele küsitluse nädalal.)

Reaalseid spordialasid nimetati 250 korral, erinevaid spordialasid tuli kokku 51. Reaalseteks ehk pärisaladeks sai kategoriseeritud kõik spordialad, milles peetakse ametlikke võistlusi. Samas võivad reaalsed võistlusspordialad, nt eespool toodud sääsepüügivõistlus ja naisekandmine olla vägagi naljakad. Favoriit on vastuste järgi suusatamine (kolmel korral täpsustati, et murdmaasuusatamine), mida mainiti 59 korral. Põhjendused on selged, nt "kuna sellega on eestlased tegelenud muistsetest aegadest. Samuti on Eesti põhjamaa." (THTG, M 17, 1.6.2017). Samas on viimase aja suusatippude puudumise (Eesti suusatajatega seotud dopingujuhtumid on kindlasti kogu spordiala mainet kahandanud, vt ka Voolaid 2014) ja lumetute talvede tõttu nii mõnigi vastaja väitnud, et suusatamine hakkab rahvusliku spordiala positsiooni kaotama: "Mõni aeg tagasi pidasin eestlaste rahvusspordiks suusatamist, kuna selles oli eestlastel häid tulemusi. Nüüd ei oska ühte konkreetset enam välja tuua.” (THTG, N 17, 6.6.2017)

Statistilises pingereas teisel kohal on kiiking 26 korraga (lisaks ühel korral kiikumine, ühel korral külakiigel kiikumine, kahel korral lihtsalt kiikumine) ja naisekandmine 24 korraga (sh ühel korral naisevedu, ühel korral naisetõstmine $)^{6}$. Neljandat ja viiendat kohta jagavad 15 vastuses nimetatud jalgpall (ühel korral jalgpallirahvas) ja võrkpall. Järgnevad jooksmine 12 korral (kahel korral tervisejooks, ühel korral järvejooks), korvpall üheksal korral, ujumine kuuel korral ja taliujumine viiel korral (kahel korral jääaugusuplus ja ühel korral talisuplus). Viies vastuses on mainitud ka rahvatants ja köievedu. Neljal korral mainiti rahvusspordina kepikõndi, orienteerumist ja sõudmist. Kolmel korral on nimetatud maadlust, autosporti, rattasõitu, sangpommi rebimist, vigursuusatamist (ühel korral ka Kelly Sildaru ja freestyle-suusatamisena) ja maratonidel osalemist. Kahel korral esinesid discgolf, drifting ja kiirendusvõistlused, iluvõimlemine, male, tantsimine, rahvastepall ja tennis. Kõigest ühe korra esinesid sõnastusvormid motokross, motosport, autode tuunimine, kergejõustik, kettaheide, kümnevõistlus, kummikuheide, käimine, matkamine, mälumäng, pallimänguala, ratastoolisport, rogain, saalialad, teatevõistlus, tõstmine, vehklemine. Ühel korral kirjutati ka üldistavalt: "see spordiala, kus eestlastel parajasti hästi läheb" ja "spordi harrastamine kõigis valdkondades".

Rahvusspordi määratlemisel on mitmel korral spordiala võrdsustatud sportlase isikuga. Vastus võib sisaldada ainult sportlase nime, nt mitmel korral on nimetatud rahvusspordina Kelly Sildaru, aga ka Ott Tänak või Tiit Sokk. Tekib metonüümiline ülekanne ja loomulikult mõtleb vastaja sportlase asemel vigursuusatamist, autorallit või korvpalli. Konkreetse sportlase eduga põhjendatakse ka mõne spordiala rahvusspordi staatust.

Mitmel korral vastati, et ekstreemsport on tänu Kelly Sildarule saamas Eestis rahvusspordiks: 
Soiku hakkab vajuma suusatamine, samas on populaarseks saanud Kelly Sildaru (freestyle-suusatamine) (TTG, 29.5.2017).

Sarnasel mehhanismil põhinevad ka järgmised selgitused korvpalli või maadluse kohta:

Korvpall, kuna oleme saavutanud juba vene ajal kõrgeid kohti, nt Tiit Sokk (TTG, 29.5.2017).

Maadlus ikka! Kristjan Palusalu jt suurmeistrid on ju saavutanud suurepäraseid tulemusi tippvõistlusest omal ajal ning hetkel on maadlust pildil hoidnud Heiki Nabi. Kõva mees! (THTG, 6.6.2017).

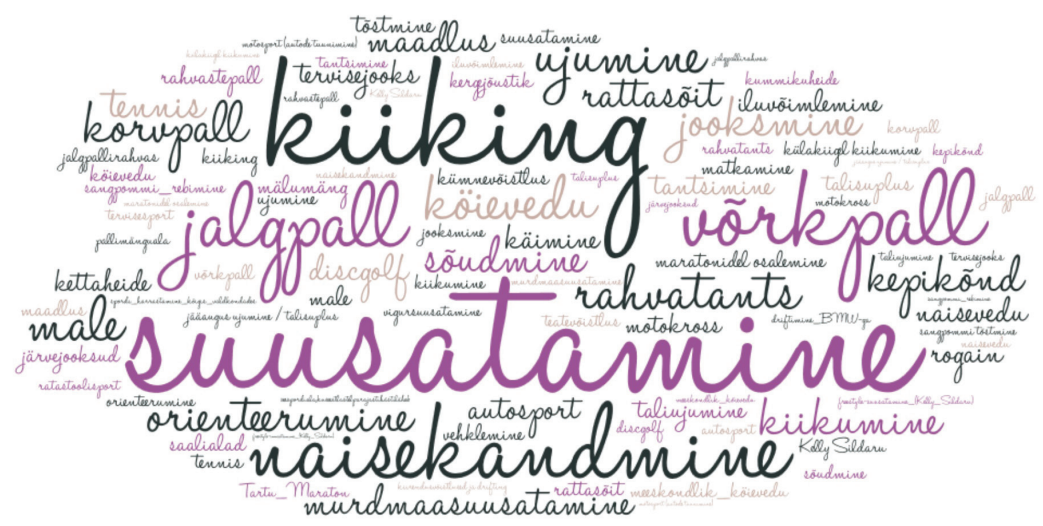

Joonis 2. Reaalsete spordialade pingereas on esikolmikus murdmaasuusatamine, Eestis leiutatud kiiking ja Soomest imporditud naisekandmine.

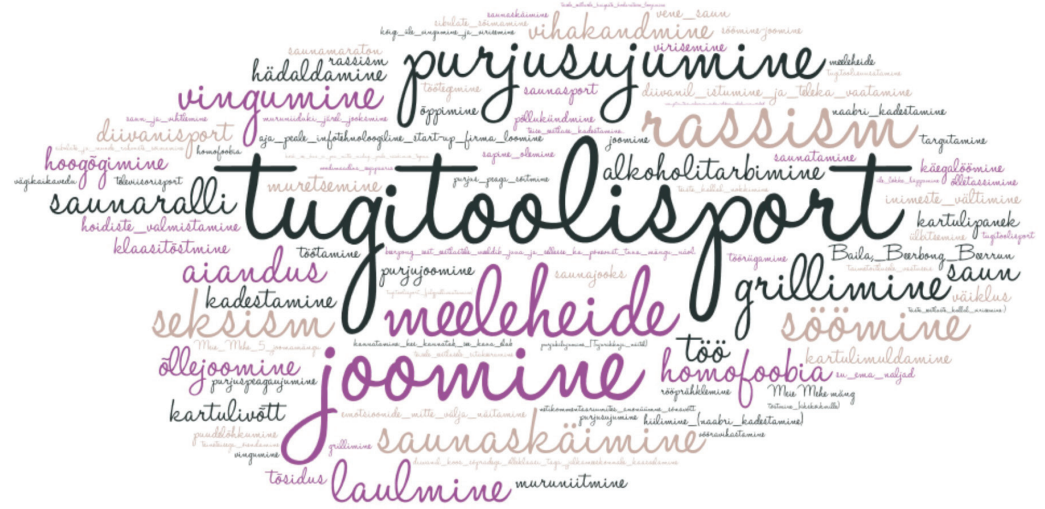

Joonis 3. Nn naljaalade edetabelis valitsevad küsitluse põhjal tugitoolisport (sh sarnased tegevused jalgpallivaatamine, diivanisport, diivanil koos sõpradega ôlleklaasi taga jalkameeskonnale kaasaelamine, tugitoolisuusatamine, diivanil istumine ja teleka vaatamine), joomine (ehk alkoholitarbimine), purjusujumine, saunaskäimine (sh saunaralli), grillimine, meeleheide, rassism, vingumine. Naljaalade nimetused on küsitletavate kõnepruugis ja nende keel muutmata. 


\section{Rahvusspordi retooriline ja irooniline mänguväli}

Käesoleva uurimuse põhieesmärgi aitavad täita vastustes välja toodud vähemtõsised spordialad, ühelt poolt rahvusspordi tõsise klišee ja teiselt poolt mõne konkreetse etniliseks peetud omaduse sõlmpunktis tekitatakse humoorikas vastuolu. Nii mõnigi vastaja andis iroonilise hinnangu kogu rahvuslike sümbolite mõttekuse temaatikale: "Eesti on üks tore rahvusriik, mis peab oluliseks mõttetuid sümboleid ja traditsioone ning üle kõige seksistlikku naisekandmist" (THTG, sugu teadmata, 17, 2.6.2017). "Tore rahvusriik" sisaldab siin irooniale kohast äraspidist tähendust.

Samasuunalist väidet sisaldab ka interneti blogipostitus: "Kuid on sel üldse tähtsust, millist ala teistele eelistada? Kõikvõimalike "rahvuslike" nähtuste otsimine näitab trööstitut identiteedikriisi. Miks peab tingimata olemas olema rahvuslik kala, ülikool, teater jne? See, mis rahvust kõige paremini iseloomustab, kujuneb aja jooksul iseeneslikult välja." (Kahro 2012). Selline suure narratiivi diskursuse kahtluse alla seadmine loobki soodsa pinnase iroonilise välja tekkeks.

$91 \mathrm{nn}$ naljaala hulgas, milles tõsimeelseid spordivõistlusi ei toimu, on juhtpositsioonil tugitoolisport. Tugitoolisporti nimetas 31 vastajat, kuid sarnased tegevused on ka ühe kirjapanekuga esindatud jalgpallivaatamine, diivanisport, diivanil koos sõpradega õlleklaasi taga jalkameeskonnale kaasaelamine, tugitoolisuusatamine, diivanil istumine ja teleka vaatamine. Sellisele valikule lisati mitmes vastuses selgitusi, nt "sest kõige lahedam on ikka ise vaadata, kuidas teised tegutsevad, ja korraldusi jagada" (TTG, N 16, 29.5.2017) või "Tugitoolisport, kui sedagi. Eks igale eestlasele meeldib vahel midagi telekast vaadata, aga ise tihti nii kaugele ei jõuta, et ise mindaks õue sportima või millegi tervislikuga tegelema :)" (THTG, M 17, 2.6.2017).

"Vaadatakse nt jalg- või korvpalli kommenteerides vigu ja mida paremini teha, kuigi ise selle spordiga isegi ei tegeleta" (THTG, M 18, 6.6.2017).

16 korda esitati rahvusspordina saunaskäimine (sh saunaralli, saun ja vihtlemine, saunatamine, saunamaraton, saunasport), mis on kohalikus kultuuris ja traditsioonilises argielus olnud aegade vältel tähtsal kohal.

12 korda oli rahvusspordina mainitud joomine (sh erinevad sõnastusvormid alkoholitarbimine; õllejoomine; klaasitõstmine, purjujoomine, uue pitsi täis valamine: mida rohkem valad, siis võidad). Lisatud on põhjendusi, nt "Juuakse nii üksi kui kollektiivselt, nii viina kui õlut, nii väljas kui kodus. Ma usun, et me oleme selles tõesti head!" (THTG, M 18, 6.6.2017). Alkoholiga liialdamine on Eestis probleem, mida kinnitavad erinevad aruanded ja rahvusvahelised raportid (nt 2012. aasta andmete järgi OECD raportis oli Eesti keskmise alkoholitarbimise poolest esikohal). Väga tõsise riskikäitumise kui negatiivse nähtuse presenteerimine rahvusspordina on iroonilise alatooniga. Selle kategooria alla 
kuuluvad ka kahel korral mainitud Meie Mehe joomamängud, mis on populaarsed naljad (tegemist on rahvaliku bändi Meie Mehe loodud humoorikate mängudega stiilis: viis eestlast joovad ära kümme pudelit viina, üks neist valitakse välja ja ta peidab ennast kappi. Teised peavad ära arvama, kes neist peitis kappi, omavaheline arutelu on lubatud jne, https:/www.youtube.com/ watch?v=9d1YQuYGNsk). Mitmel korral on nimetatud eesti rahvusspordina ka rahvusvaheliselt tuntud joomismänge, nt Baila, Beer Bong, Beer Run.

Üheksa korda on Eesti rahvusspordialaks pakutud purjusujumine (purjakilujumine Tujurikkuja näitel) ja üks kord esitatud purjuspeaga sõitmine kinnitavad alkoholitarbimise järgset levinud riskikäitumist kui tõsist probleemi, mis on pidevalt avalikkuse aruteludes. Alkoholitarbimisele lisaks nimetati paaril korral ka muid lihtsamaid sõltuvusi, nt söömine, hoogõgimine, mis võivad olla eestlase igapäevaelustressist tingitud tegevused. Aga pakutud alade hulgas leidus ka vastuseis moodsa ühiskonna kaasnähtusele taimetoitlusele.

Eraldiseisva iroonilise kategooriana saab eristada rahvuslikud tööd ja tegevused. Üldisemalt toodi ühekordsete sõnastusvormidega välja töö, töötamine, töötegemine, töörügamine, aja peale infotehnoloogiline start-up-firma loomine, puudelõhkumine. Sellega haakuvad otseselt toidulauaga seotud maatööd, mis linnakeskkonnas on pigem harvaesinevad tegevused, nagu nt põllukündmine, kartulimuldamine, kartulipanek, kartulivõtt. Rahvusliku tegevusalana oli mitmel korral välja toodud aiandus ja muruniitmine (ka muruniiduki järel jooksmine), aga ka hooajalised levinud tegevused seenelkäimine, hoidiste valmistamine, grillimine.

Rahvusliku spordialana on toodud ka laulmine, mis toidab stereotüüpi eestlastest kui laulurahvast, kes "laulsid enda vabaks" (vt ka Schmidchens 2013).

Iseseisva rahvusspordi alamkategooria hõlmab rahvuslikul pinnal ilmnevaid stereotüüpseid isikuomadusi ja käitumismustreid, mis väljendavad üldjuhul pigem negatiivseid tähendusi. Neljal korral toodi välja vingumine (kõige üle vingumine ja virisemine), kolm korda mainiti ära meeleheide. Meeleheide on eestlaste rahvusliku spordialana mitmetes huumoriliikides koha põlistanud. Nt 1996. aastal levis pärast eestlaste ebaedu Atlanta olümpiamängudel populaarne naljaküsimus:

Millisel heitealal olid Eesti sportlased Atlanta olümpiamängudel kõige tugevamad? Meeleheites. (EFA I 8, 32 (3))

Nali tekib primaarselt keelemängul, mistõttu on nalja tekstuur on raskesti tõlgitav. Sama nali on levinud ka internetimeemina.

Sellesse allrühma kuuluvad emotsioonide mitte välja näitamine, hädaldamine, inimeste vältimine, käegalöömine, muretsemine, targutamine, ülbitsemine, sapine olemine, vihakandmine. 


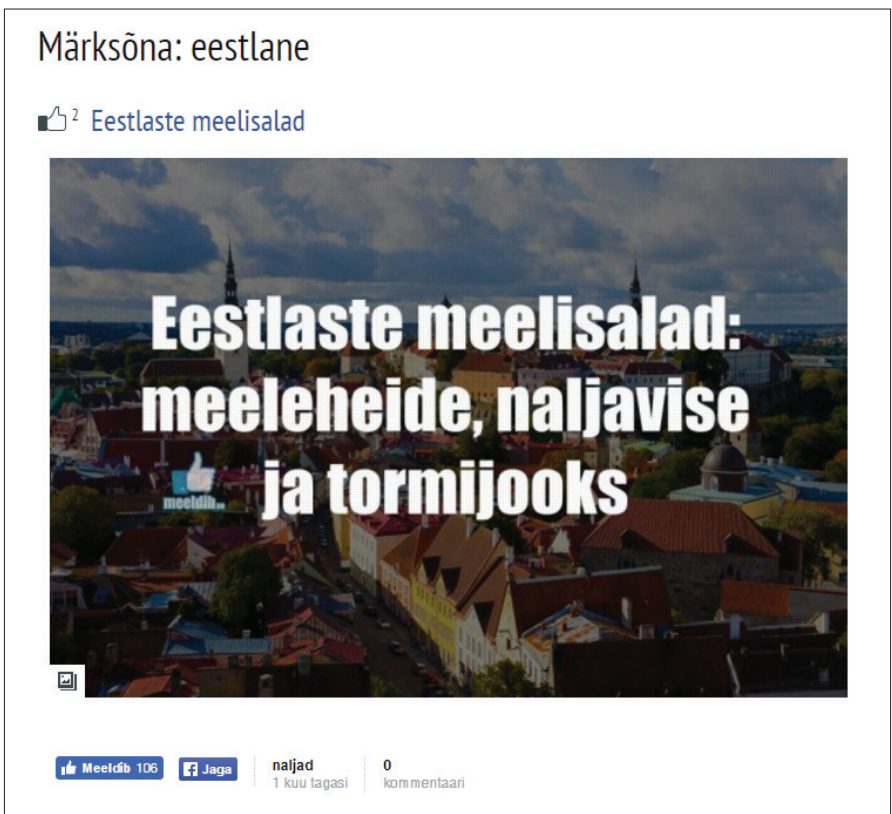

Joonis 4. Internetis levinud keelenaljal põhinev meem, milles Tallinna vanalinna kujutavale aerofotole on kirjutatud eestlaste meelisalad meeleheide, naljavise ja tormijooks (http: / / meeldib.postimees.ee/2017/05/eestlaste-meelisalad/).

Olulise vahelepõikena tuleb üldistava nimetusega meeleheite-allrühma juures rõhutada keeleressursi tähtsust. Siinjuures väärib omaette allikana nimetamist 19. oktoobril 2017 Facebookis populaarseks saanud avalikus grupis KalambuuR tehtud postitus "Eestlaste lemmik spordiala on teatavasti meeleheide. Mis spordialad võiks olla esindatud meeleheiteolümpial? Mina kvalifitseeruks ajaga võidujooksule." (KalambuuR 2017). Postitus meeldis 314 kasutajale ja kogus 213 kommentaari. "Keeleväänamisele ja sõnataltsutamisele" suunatud kogukonna loomingulist iseloomu arvestades olid postituse vastused äärmiselt mängulised ja väljapakutud naljaalade diapasoon väga lai. Võrreldes nimetamisküsitluse vastustega põhinevad aga KalambuuRis välja pakutud alad enam sõna- ja keelemängul. Kõige lihtsam viis alade parodeerimiseks näibki keeleressursiga mängimine, mis eri kasutajate interaktiivses suhtluses moodustab veereva lumepalli. Lingvistilise huumoriteooria kohaselt võib tavapärasest pisimgi tähemuutus kaasa tuua nalja esile kutsuva üllatusliku tähendusmuutuse. Siinkohal mõned KalambuuRi gruppi postitatud pärisaladest inspireeritud paroodiad:

heide-meeleheide; kindasti peaks olema meelepete-juba tundub et oled esimene ja rahvas õnnitleb, siis aga selgub, et mingi üheteistkümnes.....; eneseheide; väljaheide; meeleheiteolümpial tulemuse üle rõõmustanu diskvalifitseeriti 
hüpe/hüppamine - kõrvalhüpped; üle oma varju hüppamine; ettehüpped tundmatus kohas ka hea paraleelala, saab korraldada liikluses; järeldustessehüpe; Augushüpe olümpiaalaks!; pettehüpped, köik ainult teevad nagu hüppaksid $: D: D: D$

jooks - verejooks; ärajooksmine; kui surm ikka veel tulnud pole siis kojusajameetrijooks ja kokkut6mme; kuuli eest jooksmine; teatmejooks; altjooks\#latialt jooks\#alahoidlik jooks\#; Noorte eriala: Eestist ära jooks. Vöidab see kes esimesena üle piiri, auhinnaks meelerahu; Selle eestist ära jooksu võib ümber nimetada ka eestipäraselt kalevipoja etapiks; sarvede maha jooksmine. See võiks olla sprindiala (:):); kommijooks

kandmine - vihakandmine; sarvekandmine

kergejõustik ja raskejõustik - kas raskemeelsus on kergejõustikul; Kellele raske-, kellele kergemeelsus. Kaalukategooriad ju erinevad...

kiiking - Riigikogu saaks täies koosseisus spiikingus välja panna; Spiikingus saaks riigikogu disklafi. Alati on keegi puudu

käimine - ärakäimine; Lätiskäimine; Vanema kooli inimestele "ehal käimine”; Mahakäimine ja läbipõlemine

laskmine - minnalaskmine; ülelaskmine; ülejalalaskmine; halastuslaskmine; firmajuhtide mõõduvõtt toimub kiirkoondamises ja lahtilaskmises; aadrilaskmine; Jalgalaskmine; pussulaskmine; püksilaskmine

pall-karvapall

sukeldumine - pudelisse sukeldumine

surumine - mahasurumine, allasurumine

suusatamine - mahalaskesuusatamine

tennis - hauatennis; hauatennises võidab see, kes matab kõige rohkem võidulootusi

triatlon - Vana hea mustlase triatlon ka-jooksuga järve äärde ujuma ja jalgrattaga tagasi

tõmme - endassetõmme

tõstmine - aktsiisitõste; kaalutõstmine

vedu - vägikaikavedu

vise - odavvise; äravise; ülevise; viinaviskamine; häbivise - "Suud ja silmad häbi täis" 
Omaette suurema allrühmana esilduvad kogukonnasisesed negatiivsed suhtlemisviisid ja stereotüüpsed käitumismustrid ehk suhted "teise eestlasega", mis langevad kokku ka vanasõnalise klišeega "eestlase lemmiktoit on teine eestlane" (Laineste \& Krikmann 2015), nagu nt teineteisega õiendamine, teise eestlase kadestamine, teisele eestlasele kaigaste kodaratesse loopimine, teisele eestlasele sitakeeramine, teiste eestlaste kallal virisemine, teiste kallal nokkimine, kadestamine, naabri kadestamine, hiilimine (naabri kadestamine). Kaudsemalt on sellega seotud anonüümne sõnavõtt netikommentaariumites. Siia sobituvad ka kogukonnast väljapoole ulatuvad etnilised suhtumised, nt paaril korral nimetatud rassism, sibulate [venelaste] ja muude rahvaste sõimamine. Kaks korda toodi välja homofoobia, seksism, mis põlistavad eestlastele sageli omistatud sallimatuse stereotüüpi.

Ühekordselt vastatud rahvuslike spordialade sõnastusvormide arv oli väga suur - 80. Taas kord saab selle materjali põhjal kinnitust igasugusele folkloorikogule omane tendents ehk Zipfi seadus - kõige rohkem on üheainsa kirjapanekuga esindatud tüüpe (mis osutab nähtuse erakordselt improvisatoorsele olemusele), järsult vähem kahe kirjapanekuga esindatud tüüpe, jne, kuni jõuame skaala teises otsas üliproduktiivsete "supertüüpideni" (meie uurimuses vastavalt suusatamine ja tugitoolisport) (Krikmann 1997: 93 ja 97).

Internetiainese põhjal ilmneb, et sageli rakendavad eesti rahvusspordi kombinatsiooni probleem- ja arvamuslugude kirjutajad. Näib, et klišee “... on (uus) Eesti rahvussport” esineb eesmärgipärase kõnekaunistuse ja retoorilise sõnakõlksuna samades funktsioonides kui vanasõnad meediatekstides, kus neil on autoriteetne tähelepanuteravdaja roll (vt Granbom-Herranen \& Babič \& Voolaid 2015; Järv 1999).

Leidub tõepoolest spordirubriigist pärinevaid kirjutisi, mille sihiks on mõne uue populaarsust võitva spordiala väljatoomine, nt "Taliujumine - eestlaste uus rahvussport" (Kalam 2016), ent huviväärselt palju kohtab rahvusspordi klišeed artiklipealkirjades, nt majandusteemalistes sõnavõttudes näib see iseäranis levinud olevat: Tartu Ülikooli majandusõppejõu Jaan Õmbluse kirjutis "Uus rahvuslik spordiala - börsispekulatsioonid" (Õmblus 1997), "Üüriäri kui rahvussport" (Õhtuleht 2017), "Uus rahvussport kinnisvaras: kuni kolmandik korteritehingutest tehakse investeerimise eesmärgil" (Kreek 2017), "Rahvussport kinnisvaraturul ehk pensioni 4. sammas" (Ärileht 2016), "Melders: Koondamine on uus rahvuslik spordiala" (Blumberg 2008) kinnitavad selle klišee elujõudu majandusretoorikas.

Mitmel puhul esineb rahvusspordi klišee negatiivsete tegevuste kohta kirjutatud üldistuslugudes. Mingeid konkreetse loo kirjutamise ajal olulisi üldisemalt levinud tegevusi, suundumusi, protsesse võrreldakse kohalikule kogukonnale omase käitumisviisiga, millele antakse etniline dimensioon. Artiklis "Eestlaste 
Joonis 5. Rahvusspordi diskursus on muutuv ja reageerib nt vastavalt aastaajale: talvel võib olla Eesti rahvussport jääpurikate pildistamine - modelle on kõik räästad täis (Blaat 2010).
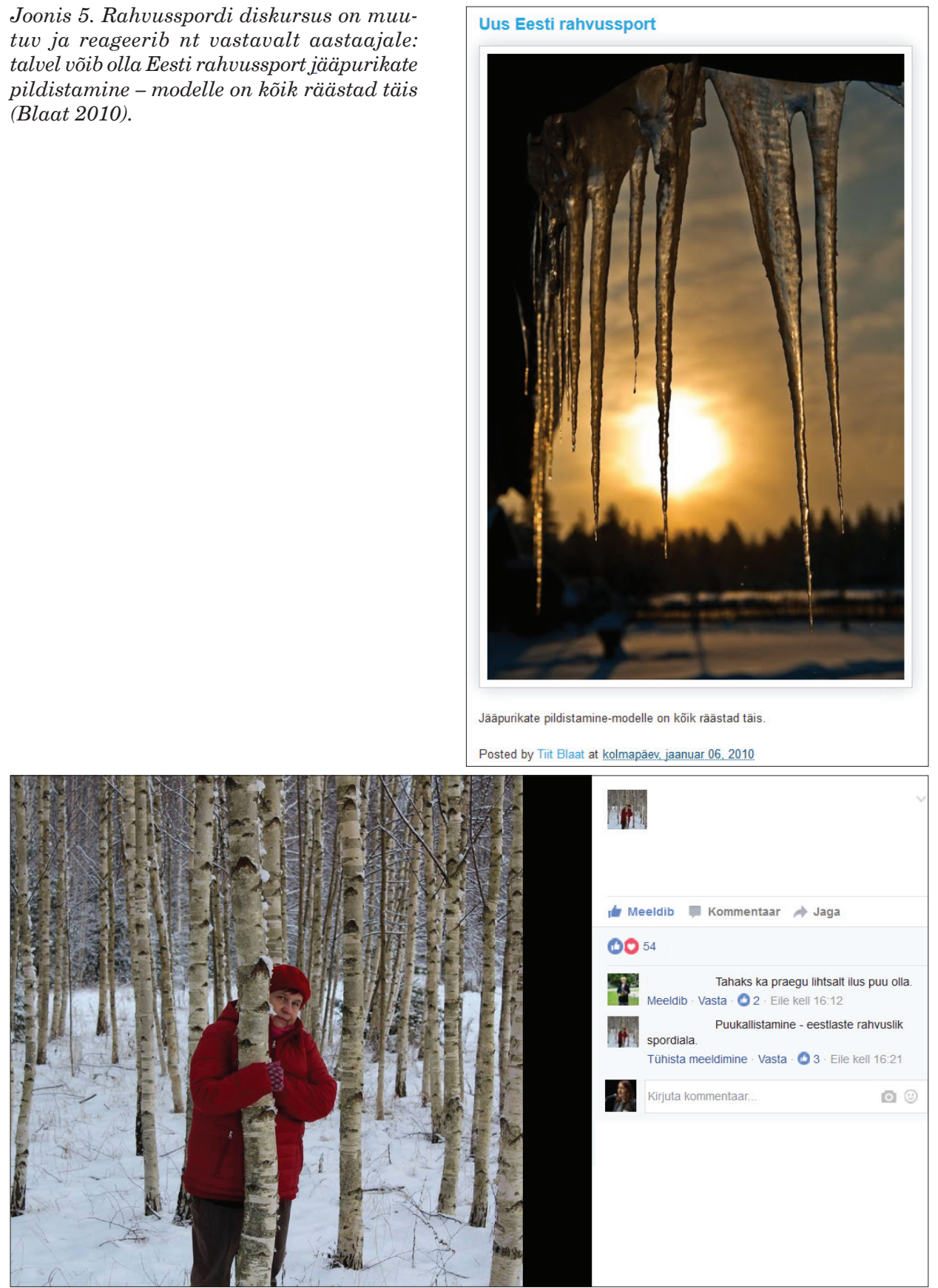

Joonis 6. Rahvusspordi malli sobib mis tahes levinud tegevus. Nt sotsiaalmeediaprofiilil esitletud puukallistamine markeerib otsest tegevust, kuid see võib olla omaette ideoloogilise maailmavaate metafoor, millega ürgeestlust (siia kuuluvad stereotüübid eestlastest kui maausku metsarahvast, levinud loodus- ja keskkonnakaitselised kodanikualgatused jne) seostatakse. Otsese ja kujundliku tähendusvälja sulam lisab vaataja silmis pildile heatahtlikku huumorit. 
rahvussport - surnuksjoomine" (Delfi 2006) kirjeldatakse suurt alkoholitööstust ja seda, kuidas "Eestis toodetakse 236 erisugust viina, millele lisanduvad 175 Vene ja sadakond Ukraina viina". Kogukonnasiseselt on need suundumused arusaadavad. Seoseid huumoriga ei pruugi üldse olla, oluline on klišee tabav ja üldistav loomus, mis täidab väga hästi pealkirjale esitatavaid nõudeid.

\section{Kokkuvõtteks}

Mõiste rahvussport on palju enamat kui pelgalt reaalsuse tähistaja, see ei tähista ainult kehalisi toiminguid ja pingutusi, vaid mõiste aitab mentaalselt iseloomustada rahvast üldlevinud meelistegevuste kaudu, olgu need siis hinnanguliselt positiivsed või negatiivsed. Kahtlemata on nii rahvusspordi reaalsel ja tõsisel kui ka nalja- ja irooniadiskursusel tähtis roll rühma identiteeditaju loomisel ja tugevdamisel. Üldistavalt võib Eesti rahvusspordiks nimetada "ala, kus eestlastel hästi läheb". Sõna "hästi” võib aga tähistada ametlikele võistlusaladele (nt suusatamine, kiiking ja naisekandmine) tõsist kiitust, ent ka viidata peenele irooniale, mis ilmneb retoorilisse klišeesse paigutatud rahvusspordi kohta. Niisiis võib "hästi" minna ka sellistel kriminaalsetel aladel, nagu nt eestlaste juveeliröövid välismaal, liiklushuligaanitsemine või lähisuhtevägivald.

Analüüsi põhitulemusena ilmneb, kuivõrd erinev ja variatiivne arusaam on eestlastel rahvusspordist. Küsitluskava vastuste järgset mitmekesist paletti rikastavad internetimeedia kirevad kasutustraditsioonid. Nimetamisküsitlusega on statistiliselt võimalik välja selgitada populaarseim spordiala nii tõsiste päriskui ka naljaalade hulgas, kuid üksmeelset kokkulepet ühe jäägitu favoriitala suhtes ilmselt ei saagi tekkida, ja katsed sellist ala forsseerida on ilmselgelt tulutud. Püüdlused meediaaruteludes ja spordiringkondades on küll pidevalt aktuaalsed, kuid ühiskondliku kokkuleppeni jõudmine käesoleva uurimuse valguses peaks nõudma mingit erilist motivaatorit.

Kehtib statistilisest lingvistikast tuntud Zipfi reegel, mida konkreetsele folklooriainesele üle kandes saame pidada loomulikuks ainukordselt nimetatud rahvuslike spordialade rohket variatiivsust. See tendents kehtib nii ametlike kui ka naljaalade korral. Kui materjali juurde koguda, siis mõlema valdkonna favoriitalade (suusatamine ... ja tugitoolisport ...) nimetamiskordade statistiline ülekaal küll kasvaks, aga lisanduks tohutult palju uusi, tõenäolisemalt just nn nalja-alasid.

Retoorilises diskursuses ongi uute ideede väljamõtlemine eesmärk, siin töötab üldnimetaja "Eesti rahvussport" klišeena, mida uutes sotsiokultuurilistes tingimustes täidetakse pidevalt uudse, värske ja vaimuka ainesega. Etniline 
enesepilge saab rohke improvisatsiooni allikaks ja eestlase omamoodi mõõdupuuks. Siinse uurimuse allikate põhjal on iroonilise diskursuse favoriidid tugitoolisport, saunaskäimine ja alkoholitarbimine. Eraldi allvormidena tulevad esile mitmesugused negatiivseks peetud sõltuvustegevused (purjutamine, töönarkomaania, liikluseeskirjade rikkumine vmt). Omaette etnilise enesepilke allrühmana esilduvad negatiivsed suhtlemisviisid (naabri kadestamine, võõraviha vmt), samuti stereotüüpiliselt etniliseks peetud isikuomadused meeleheide, liigne muretsemine, vihapidamine). Samas esineb naljaalade hulgas ka neutraalseid (isegi pigem positiivseid) tegevusi, mille hulgast võib esile tuua mõningad hooajategevused, nt seenelkäimine, hoidiste tegemine, jääpurikate pildistamine. Osa nalja-alasid luuakse esijoones rikkalikke keelelisi võimalusi rakendades (nt heide-paroodiad - meeleheide, eneseheide, väljaheide; hüpe ja hüppamine - kõrvalhüpped; üle oma varju hüppamine; ettehüpped liikluses).

Ühe tabava rahvapärase klišee "Eesti rahvuslik spordiala on ..." rikkalik variatiivsus kinnitab rahva keeleloome suurt potentsiaali, mida saadavad mängulised, meelelahutuslikud, naljast, aga ka irooniast kantud eesmärgid. Niisiis võiks eestlaste uus rahvussport olla peale rahvusspordiala pidevate otsingute uute rahvusspordialade väljamõtlemine...

\section{Tänuavaldus}

Uurimus on seotud Eesti Teadusagentuuri institutsionaalse uurimisprojektiga IUT 22-5, seda toetas Euroopa Liit Euroopa Regionaalarengu Fondi kaudu (Eesti-uuringute Tippkeskus TK 145 - CEES). Autori eriline tänu kuulub artikli anonüümsetele retsensentidele kõigi asjakohaste märkuste ja soovituste eest. Aitäh ka Eesti Spordi- ja Olümpiamuuseumile, kes vahendas küsitlust sotsiaalmeedia kaudu, ning kõigile küsitlusele vastanutele. 


\section{Kommentaarid}

1 Arutelud eestlaste rahvusspordi teemadel pole midagi uut, peaaegu 100 aasta tagusest, 1922. aasta Eesti Spordilehest saame lugeda vestevormis artiklit sellest, kuidas toonane haridusministeerium rahvalikku sporti toetab. "Rahvalik sport missugune peaks see küll olema? On see meie rahva populaarsem, armastatavam spordiala või mäng, vastav iseäranis meie rahva iseloomule ja soodne meie raassilise omapära kujundamiseks ? Nagu inglastel jalgpall, Skandinaavia rahvastel talvesport, KeskEuroopa rahvastel rattasport või midagi muud. Meie teada ei ole eestlastel senni sarnast rahvalikku sporti veel olemas, pääle sõrmetõmbamise ja vägipulga vedamise, mis aga veel sarnast tähtsust pole jõudnud omandada ja ka vist haridusministeeriumi poolt rahvaliku spordi all pole mõeldud. See oleks siis ka rahvuslik sport. Rahvalik sport aga tahab siin vist teist mõistet rõhutada, alla kriipsutada n.n. definitsiooni isiklikuks ja rühmspordiks, pooldades nähtavasti viimast, s.o. jalgpalli ja teisi mängusid.” (ES 1922)

${ }^{2}$ On küllalt näiteid ja uurimusi (nt Pöysä 2004) sellest, kuidas rahvusriigi eest võistlevad edukalt mõne teise rahvuse esindajad. Käesoleva uurimuse vaateväljast jääb see aspekt välja, küll aga vajaks see Eesti materjali ja näidete varal tulevikus eraldi käsitlemist.

3 Eestlaste esimese olümpiamedali võitis maadleja Martin Klein 1912. aastal Stockholmis, kus ta pidas seniajani kõigi aegade pikima maadlusmatši (11 tundi 40 minutit), mille võit tõi talle hõbemedali ja millega ta jõudis ka Guinnessi rekordite raamatusse. Eesti esimene olümpiavõitja Kreeka-Rooma maadluses oli Eduard Pütsep Pariisis 1924. Eesti esimene olümpiavõitja vabamaadluses oli Osvald Käpp Amsterdamis 1928. Kristjan Palusalu võitis 1936 Berliinis kulla nii Kreeka-Rooma kui ka vabamaadluses. Kui vahepealsetel aegadel võis maadlusspordis täheldada mõningast madalseisu, siis nt Heiki Nabi olümpiahõbe 2012. aastal Londoni olümpiamängudel Kreeka-Rooma maadluses taastas huvi ala vastu. Esiletõstmist väärivad tõstjate saavutused - eestlaste esimene olümpiavõitja oli tõstja Alfred Neuland, kes võitis kulla kaaluklassis alla 67,5 kilo 1920. aastal Antwerpenis. Lisaks peeti Tallinnas 1922. aastal tõstmise MM-võistlused, millel Eesti sai viiest kullast kolm ja mis korraldati Estonia teatris ka see on rahvuslikust vaatepunktist märgilise tähtsusega. Eesti kõige edukama tõstja Jaan Taltsi kontol on lisaks kahele olümpiamedalile (1968 Mexicos hõbe, 1972 Münchenis kuld) ka 41 maailmarekordit.

${ }^{4}$ Võistluste esindajate sõnul on sääsepüüdmine lõbus, lihtne ja seltskondlik tegevus, mis ei vaja eelnevat treeninglaagrit ja millega saavad hakkama kõik (Delfi 2010). Võistelda saab nii individuaalselt kui ka meeskondlikult (võistkonnas peab olema kolm liiget). Igale võistlejale eraldatakse nööriga väike maalapike, kust ta ei tohi välja minna. Püüdmise aeg on 15 minutit, ja kes rohkem sääski saab, on võitja. 2017. aasta Eesti meister sääsepüüdmises kogus 18 sääselaipa. (Kula 2017: 4)

5 Mõistemetafoor ELU ON võISTLUS haakub mitmete muude elu kohta esinevate defineerivate sedastuste või üldistavate väidetega, kus üldistuste aluseks on kognitivistide käsitletav metafoori põhivalem 'A on B', mis väljendab 1) kas kahe termini identsust või 2) kategoriseerivat väidet - sarnasuse alusel ühe objekti paigutamine kategooriasse või alamkategooria paigutamine ülemkategooriasse (vt ka Turner 1991: 196-197, 199). Mõistemetafoori ELU ON TEEKOND kohta vt Õim 2007.

6 1992. aastast alates peetakse Soomes, Väike-Maarja valla sõprusvallas Sonkajärvil naisekandmise võistlusi, 1996. aastast toimuvad need võistlused maailmameistrivõistlustena. Eestis on naisekandmise meistrivõistluste kaubamärgi kasutamisõigus 
Väike-Maarja vallal, kus on võistlusi vahelduva eduga peetud alates 1998. aastast. Folkloristlikult on huvitav, et võistlus põhineb ühel Sonkajärvi ajaloolisel pärimusel. Legend pajatab, et 19. sajandi lõpus tegutses sealkandis röövlijõuk, keda juhtis mees nimega Rosvo-Ronkainen. Tema jõuku saamiseks pidid mehed end naisekandmisega proovile panema. Sel ajal oli naise röövimine naaberküladest üldiselt levinud komme. (Tobreluts 2014)

\section{Allikad}

EFA - Eesti folklooriarhiivi rahvaluulekogu (Eesti Kirjandusmuuseumi Eesti Rahvaluule Arhiiv).

THTG - mais ja juunis 2017 Tartu Hugo Treffneri Gümnaasiumi õpilaste (vanuses 16-18 aastat) seas korraldatud küsitluse vastused asuvad Eesti Kirjandusmuuseumi folkloristika osakonna teadusarhiivis (EFITA.KK.039).

TTG - juunis 2017 Tartu Tamme Gümnaasiumi õpilaste (vanuses 16-18 aastat) seas korraldatud küsitluse vastused asuvad Eesti Kirjandusmuuseumi folkloristika osakonna teadusarhiivis (EFITA.KK.039).

KalambuuR 2017, 19. oktoober (https://www.facebook.com/groups/kalambuur/ permalink/10155408333769702/ - 7. november 2017).

\section{Kirjandus}

Annus, Epp 2000. Postmodernism kui hilissotsialismi kultuuriloogika. Keel ja Kirjandus 11, lk 769-780 (www.digar.ee/arhiiv/en/download/143161 - 7. november 2017).

Annus, Epp 2006. Oponeering Piret Viirese doktoriväitekirjale "Postmodernism eesti kirjanduskultuuris”. 30. VI 2006. Käsikiri autori valduses.

Attardo, Salvatore \& Raskin, Victor 1991. Script theory revis(it)ed: joke similarity and joke representation model. Humor 4 (3-4), lk 293-347 (doi:10.1515/humr.1991.4.3-4.293).

Blaat, Tiit 2010. Uus Eesti rahvussport. Blaat. Pildistan, mida näen, räägin, mida mõtlen, 6. jaanuar (http://tiitblaat.blogspot.com/2010/01/uus-eesti-rahvussport.html 20. mai 2017).

Blumberg, Kärt 2008. Melders: Koondamine on uus rahvuslik spordiala. Äripäev, 17. detsember (http://www.aripaev.ee/uudised/2008/12/17/Melders_Koondamine_on_ uus_rahvuslik_spordiala - 7. november 2017).

Brubaker, Rogers 2009. Ethnicity, Race, and Nationalism. Annual Review of Sociology 31, lk 21-42 (doi: 10.1146/annurev-soc-070308-115916).

Delfi 2006. Eestlaste rahvussport - surnuks joomine. Delfi, 6. mai (http://www.delfi.ee/news/ paevauudised/eesti/eestlaste-rahvussport-surnuks-joomine?id=12826050 - 7. november 2017). 
Delfi 2010. Tartumaal toimuvad Eesti esimesed sääsepüüdmise meistrivõistlused. $w w w$. Delfi.ee, 8. juuni (http://eestielu.delfi.ee/archive/tartumaal-toimuvad-eesti-esimesedsaasepuudmise-meistrivoistlused?id=31552821 -7 . november 2017).

ES $1922=$ Rahvalik sport. Vestekujulised tõsiasjad. Eesti Spordileht $\mathrm{nr} 44 / 48,10$. detsember, lk 524-525 (http://dea.digar.ee/cgi-bin/dea?a=d\&d=eestispordileht19221210.2.16 7. november 2017).

Giora, Rachel \& Attardo, Salvatore 2014. Irony. Attardo, Salvatore (toim). Encyclopeda of Humor Studies Vol 1. Los Angeles, London, New Delhi, Singapore, Washington DC: Texas A\&M University-Commerce, lk 397-402.

Granbom-Herranen, Liisa \& Babič, Saša \& Voolaid, Piret 2015. Proverbial Expressions in Newspapers. A Study in Estonia, Finland and Slovenia. Traditiones : zbornik Instituta za slovensko narodopisje in Glasbenonarodopisnega inštituta ZRC SAZU = Acta Instituti ethnographiae et Instituti ethnomusicologiae Slovenorum 44 (3, 1), lk 5-32 (http://isn. zrc-sazu.si/files/file/Traditiones/Traditiones_44_3_separati/1_Branbom_Babic_Voolaid. pdf -7 . november 2017).

Hussar, Lauri 2012. Eesti otsib rahvussporti. Postimees, 26. jaanuar (http://arvamus. postimees.ee/716938/lauri-hussar-eesti-otsib-rahvussporti - 7. november 2017).

Hutcheon, Linda 1994. Irony's Edge: The Theory and Politics of Irony. London ja New York: Routledge.

Ingver, Argo 2017. Varnjas toimusid sääsepüüdmise Eesti meistrivõistlused. Delfi, 18. juuni (http://tv.delfi.ee/uudised/paevauudised/delfi-fotod-ja-video-varnjas-toimusidsaasepuudmise-eesti-meistrivoistlused?id=78597644 -7 . november 2017).

Järv, Risto 1999. Is Providing Proverbs a Tough Job? References to Proverbs in Newspaper Texts. Folklore: Electronic Journal of Folklore 10, lk 77-107 (doi: 10.7592/ FEJF1999.10.rjrv).

Kahro, Marek 2012. Geenid või kombed? Marek Kahro mõtteait, 13. august (http:// marekkahro.blogspot.com/2012/08/geenid-voi-kombed.html - 7. november 2017).

Kalam, Laura 2016. Taliujumine - eestlaste uus rahvussport. Sportland Magazine, 13. detsember (http://www.sportlandmagazine.com/est/taliujumine-eestlaste-uusrahvussport/ - 20. juuli 2017).

Kreek, Romet 2017. Uus rahvussport kinnisvaras: kuni kolmandik korteritehingutest tehakse investeerimise eesmärgil. Ärileht.ee, 14. veebruar (http://arileht.delfi.ee/news/ uudised/uus-rahvussport-kinnisvaras-kuni-kolmandik-korteritehingutest-tehakseinvesteerimise-eesmargil?id=77226298 -7 . november 2017).

Krikmann, Arvo 1997. Sissevaateid folkloori lühivormidesse I: Põhimõisteid, žanrisuhteid, üldprobleeme. Tartu: Tartu Ülikooli Kirjastus (http://folklore.ee/ kriku/PARINTRO/ Parintro.pdf - 7. november 2017).

Kula, Kertu 2017. Peipsi ääres astusid võistlustulle parimad sääsepüüdjad. Tartu Postimees, 18. juuni (https://tartu.postimees.ee/4150293/galerii-ja-video-peipsi-aaresastusid-voistlustulle-parimad-saasepuudjad - 7. november 2017). 
Laineste, Liisi 2014. Translated identity: Recipes as part of nation-building in Estonia. First International Conference on Food and Culture in Translation (FaCT) - Forli, 22-24 May 2014, lk 25.

Laineste, Liisi \& Krikmann, Arvo 2015. 'The favourite food of an Estonian is another Estonian': A paremiological insight into national communication style. Chłopicki, Władysław (toim). Culture’s Software - Communication Styles. Cambridge: Cambridge Scholars Publishing, lk 89-108.

Lään, Vello (koost) 2002. Korvpall. Tallinn, Tartu: Eesti Korvpalliliit.

Lääne, Tiit 2007. Suusatamine - Eesti rahvussport. Tallinn: Ajakirjade Kirjastus.

Paal, Gunnar 2017. Eesti lipp olümpiarõngaste kohal. Tartu: Eesti Spordi- ja Olümpiamuuseum.

Pöysä, Jyrki 2004. "Finnishness" and "Russianness" in the making: sport, gender and national identity. Siikala, Anna-Leena \& Klein, Barbro \& Mathiesen, Stein R. (toim). Creating Diversities. Folklore, Religion and the Politics of Heritage. Studia Fennica Folkloristica 14. Helsinki: Suomalaisen Kirjallisuuden Seura, lk 54-68.

Rand, Erki 2007. Mis sobiks Eestile rahvusspordiks? Eesti Päevaleht, 15. detsember (http:// epl.delfi.ee/news/online/mis-sobiks-eestile-rahvusspordiks?id=51112611 -7 . november 2017).

Schmidchens, Guntis 2013. The Power of Song. Nonviolent National Culture in the Baltic Singing Revolution. New Directions in Scandinavian Studies. Seattle and London: University of Washington Press. Copenhagen: Museum Tusculanum Press.

Siimann, Mart 2014. Sport ja Eesti Olümpiakomitee (http://www.eok.ee/sites/default/ files/artiklid/2014/V\%20SP\%20Siimann.pdf - 20. juuli 2017, ei ole enam leitav).

Särg, Taive 2015. Vägivallatus armastab vabadust. Guntis Šmidchens. The Power of Song. Mäetagused 60, lk 173-181 (http://www.folklore.ee/tagused/nr60/tutvus.pdf 7. november 2017).

Tajfel, Henry \& Turner, Jonathan 1979. An integrative theory of intergroup conflict. Austin, William G. \& Worchel, Stephen (toim). The Social Psychology of Intergroup Relations. Monterey, CA: Brooks-Cole, lk 33-47.

Tamm, Marek 2003. Monumentaalne ajalugu: Mida me mäletame Eesti ajaloost? Vikerkaar 10-11, lk 60-68.

Tobreluts, Ilve 2014. Kas naisekandmisvõistluste aeg Väike-Maarjas sai ümber? Eestielu. ee Delfi, 31. mai (http://eestielu.delfi.ee/laanevirumaa/sport/kas-naisekandmisvoistlusteaeg-vaike-maarjas-sai-umber?id=68784509 -20 . juuli 2017).

Turner, Mark 1991. Reading Minds. The Study of English in the Age of Cognitive Science. Princeton, New Jersey: Princeton University Press.

Undusk, Rein (toim) 2008. Rahvuskultuur ja tema teised. Collegium litterarum 22. Tallinn: Underi ja Tuglase Kirjanduskeskus. 
Õhtuleht 2017. Üüriäri kui rahvussport. City24.ee, 11. mai (http://www.ohtuleht. ee/804205/uuriari-kui-rahvussport - 7. november 2017).

Õmblus, Jaan 1997. (http://blog.ekspress.ee/Arhiiv/Vanad/1997/04/arvamus.html 15. mai 2014, ei ole enam leitav).

Vaher, Vaapo 2010. Jalgpall hingede öös. Vutist eesti kultuuriloos. Tallinn: Pegasus.

Vahtramäe, Ell 2015. Eesti toit ja rahvustoit. Folkloristide X talvekonverents "Mälu. Meenutamine. Muistend: Pühendatud Aino Laaguse 70. sünniaastapäevale” 26.-27. veebruaril 2015 Taevaskoja Puhkekeskuses: Teesid. Tartu: Tartu Ülikooli eesti ja võrdleva rahvaluule osakond, lk 30 (http://www.ut.ee/folk/files/talvekonverentsi_teesid_2015.pdf - 7. november 2017).

Vaiksaar, Arnold 1999. Rahvusliku spordiresultaadi dünaamikast. Vaiksaar, Arnold (koost, toim). Eesti Spordiajaloo Seltsi II teadusliku konverentsi "Sport Eestis 1940-1991" materjalid. Eesti Spordimuuseumi ja Eesti Spordiajaloo Seltsi Toimetised 3, Tartu: Eesti Spordimuuseum, Eesti Spordiajaloo Selts, lk 6-39.

Viires, Piret 2008. Postmodernistlik mäng ja rahvuslikkus. Undusk, Rein (toim). Rahvuskultuur ja tema teised. Collegium litterarum 22. Tallinn: Underi ja Tuglase Kirjanduskeskus, lk 209-216.

Voolaid, Piret 2003. Jaanuar, veerpalu, märts, aprill, mae ... Pilk spordimaailma läbi folklooriprisma. Mäetagused 21, lk 193-221 (doi: 10.7592/MT2002.21.spordifolkloor).

Voolaid, Piret 2014. Olümpiavõitja kui rahvuskangelane: folkloristlik vaade ühele dopingujuhtumile. Mäetagused 58, lk 53-84 (doi: 10.7592/MT2014.58.voolaid).

Õim, Katre 2007. Metafoor ELU ON TEEKOND ebaõnne-väljendites. Erelt, Mati \& Erelt, Tiiu (toim). Emakeele Seltsi aastaraamat. Tallinn: Emakeele Selts, lk 179-194.

Ärileht 2016. Rahvussport kinnisvaraturul ehk pensioni 4. sammas. Ärileht.ee, 9. detsember (http://arileht.delfi.ee/news/uudised/rahvussport-kinnisvaraturul-ehk-pensioni-4sammas?id=76541266 - 7. november 2017). 


\title{
Summary
}

\section{'The national sport of Estonia': From big narratives to variegated and humorous/ironic colloquial rhetoric}

\author{
Piret Voolaid \\ Senior Research Fellow / Executive Manager of the Centre of Excellence in Estonian \\ Studies \\ Department of Folkloristics, Estonian Literary Museum \\ piret@folklore.ee
}

Keywords: colloquial language, ethnic stereotypes, figurative language, irony, national identity, national sport of Estonia, sport lore

The paper focuses on the usage of phrases connected to both the serious and humorous representation of (new) Estonian national sports in Estonian online media in the past few years. I suggest to differentiate between official/formal/serious and unofficial/informal/ humorous fields of sport, where at one end of the scale there are sports that are based on long historical, cultural, and geographical traditions (wrestling, cross-country skiing, etc.), in which Estonian sportsmen have received international recognition and which have always attracted a big number of amateurs, professionals, and fans. At the other end, there are those "pseudo-sports" that are, above all, expressions of folk creativity; these appear as elements of linguistic-folkloric communication. Within this discourse, a new national sport may be throwing oneself in front of a moving car, picking mushrooms, cursing politicians, laying off workers, spotting speeders in unmarked police vehicles, drinking oneself to death, etc. These are used to bring out the local, stereotypical features of the nation. The tendency of linking specific fields of sport to the ethnic dimension is motivated by the mechanisms of identity creation. At the same time, it points to the cultural importance of sports. Such ironic rhetoric may have a universal dimension. The purpose of the article is to describe and explain these fields of meaning, focusing on the variations and humorous aspects in the data. Sports as such loses its significance in the process and the emotional, stereotype-based and self-ironical point of view prevails.

The source data of this study were collected by employing various methods and study environments. The main source comprises 250 responses to a short questionnaire carried out in spring 2017 via forms or handwritten pages. The main result of the analysis reveals how differently Estonians feel about the national sport of their country. The variegated palette of opinions from the responses received pursuant to the survey plan is enriched by the usage traditions established via Internet media. Statistically it is possible to determine the most popular sport among serious or humorous sport disciplines, but there will most likely never be consensus about a favourite sport. Any attempts to forcefully establish a discipline of this kind are clearly useless.

In rhetorical discourse the conjuring up of new elements is the aim. Here the general denomination of the 'national sport of Estonia' works as a cliché that is constantly being reloaded with new and humorous subject matter in compliance with new socio-cultural 
conditions. Ethnic self-ridicule becomes a source of abundant improvisation. The favourites in ironic discourse are armchair sport, going to the sauna, and consuming alcohol. Negative addictive behaviour (be it drinking, being a workaholic, violating traffic regulations or something else) stands out as a separate sub-form of national sport. Negative forms of communication (being jealous of your neighbour, intolerance of others, etc.) and personal characteristics that are considered to be stereotypically ethnic (desperation, worrying, bearing a grudge) form an independent subgroup of ethnic self-ridicule. At the same time, there are also neutral (sometimes even positive) activities among humorous elements, such as seasonal activities, e.g. mushrooming and photographing icicles. The great variety of the cliché "The national sport of Estonia is...", which is so relevant and popular, is testament to the potential of the linguistic creative processes of Estonians, accompanied by playful and entertaining goals driven by joy and merriment. 